\title{
Ultrasound Elastography in the Assessment of the Intestinal Changes in Inflammatory Bowel Disease-Systematic Review
}

\author{
Dominika Ślósarz, Elżbieta Poniewierka, Katarzyna Neubauer*(D) and Radosław Kempiński *(D) \\ Department of Gastroenterology and Hepatology, Wroclaw Medical University, Borowska 213, \\ 50-556 Wroclaw, Poland; dominika.slosarz@student.umed.wroc.pl (D.Ś.); \\ elzbieta.poniewierka@umed.wroc.pl (E.P.) \\ * Correspondence: katarzyna.neubauer@umed.wroc.pl (K.N.); radoslaw.kempinski@umed.wroc.pl (R.K.)
}

Citation: Ślósarz, D.; Poniewierka, E.; Neubauer, K.; Kempiński, R. Ultrasound Elastography in the Assessment of the Intestinal Changes in Inflammatory Bowel Disease-Systematic Review. J. Clin. Med. 2021, 10, 4044. https://doi.org/ $10.3390 /$ jcm10184044

Academic Editors: Daniele Piovani and Stefanos Bonovas

Received: 14 August 2021

Accepted: 4 September 2021

Published: 7 September 2021

Publisher's Note: MDPI stays neutral with regard to jurisdictional claims in published maps and institutional affiliations.

Copyright: (c) 2021 by the authors. Licensee MDPI, Basel, Switzerland. This article is an open access article distributed under the terms and conditions of the Creative Commons Attribution (CC BY) license (https:// creativecommons.org/licenses/by/ $4.0 /)$.
Abstract: Inflammatory bowel disease (IBD) is a chronic condition affecting primarily the gastrointestinal tract and characterized by growing incidence worldwide. Complex diagnostic process of IBD as well as evaluation of disease activity and intestinal complications that are crucial for the therapeutic decisions, require repetitive, invasive, expensive, time-consuming and poorly tolerated tests. In contrast to endoscopy and computed tomography, ultrasound elastography (UE) is noninvasive, non-radiating and non-contrasting dependent tool which might be utilized in IBD patients for the assessment of the intestinal changes. Therefore, we performed the systematic review to evaluate the possible application of the ultrasound elastography for assessment of the intestinal changes in IBD. After the search of three databases: PubMed, World of Knowledge and Scopus, we identified 12 papers which were included in the final analysis. The majority of the studies were focused on the evaluation of the symptomatic ileal/ileocolonic strictures in Crohn's disease patients that required surgical resection. Only one study concerned ulcerative colitis. The authors evaluated different UE techniques: strain elastography (SE), acoustic radiation force impulse (ARFI) and shear wave elastography (SWE). Results were expressed with semi-quantitative color mapping and strain measurement. Histological scores of inflammation and fibrosis in Crohn's disease were used as a reference test in the majority of studies. Ultrasound elastography seems to be a promising novel imaging technique supporting evaluation of the intestinal strictures in Crohn's disease patients in respect to fibrosis detection as well as differentiation between fibrosis and inflammation. However, further research is needed to establish the position of ultrasound elastography in IBD management.

Keywords: ultrasound elastography; strain elastography; acoustic radiation force impulse; shear wave elastography; inflammatory bowel disease; ulcerative colitis; Crohn's disease; fibrosis

\section{Introduction}

Inflammatory bowel diseases (IBD) are chronic, relapsing and remitting conditions affecting primarily the gastrointestinal tract characterized by rising incidence worldwide [1] The major types of IBD are ulcerative colitis (UC) and Crohn's disease (CD). UC is a chronic mucosal and submucosal inflammation limited to the colon and rectum, whereas in CD, a whole intestinal wall is inflamed and every part of the gastrointestinal tract may be involved [2]. Still, both conditions share similar and not fully elucidated pathogenesis including interplay between genetic, microbiological and environmental factors. According to the recently published study, genetic vulnerabilities in IBD are concerning pathways regulating homeostasis between the immune system, mucosal barrier tissues and the microbiome [3]. As a consequence of complex pathogenesis, single diagnostic test for IBD is still missing. The diagnosis is established based on the combination of symptoms, endoscopic tests and imaging examinations (computed tomography, (CT) and/or magnetic resonance $(\mathrm{MR}))$ together with histopathological assessment. Invasive, time-consuming and expensive endoscopy with biopsy sampling for histopathology evaluation remains 
a crucial diagnostic tool in IBD [4]. Further, as clinical symptoms poorly correlate with intestinal disease activity, this last one is evaluated by a set of laboratory indices (C-reactive protein (CRP), fecal calprotectin), endoscopy and imaging tests. However, $\mathrm{CT}$ should be reserved for emergency cases due to high radiation exposure [5]. Furthermore, assessment of the effectiveness of treatment strategy requires endoscopy as other indices of mucosal healing $(\mathrm{MH})$ are still unavailable [6].

In recent years, there has been growing interest in the utility of ultrasound elastography (UE) as a novel tool to evaluate tissue stiffness [7]. Over time, literature has elaborated on elastography implications in assessment of liver, breast, thyroid, kidney, prostate, lymph nodes and pancreas [8-11]. Elastography techniques might be divided into qualitative and quantitative methods $[12,13]$. Strain elastography (SE) is a basic qualitative elastography technique. Quantitative methods are used in transient elastography (TE), point shear wave elastography (pSWE), also known as acoustic radiation force impulse (ARFI) and shear wave elastography (SWE). SE is based on palpation with transducer or physiological patient movement to generate pressure on tissues and their displacement, which are decreased in cases of stiffer structure. The use of both ultrasound imaging and elastography lead to tissue stiffness color mapping [12]. In turn, TE uses an ultrasound probe and transducer supplying low frequency $(50 \mathrm{~Hz})$ vibration to induce underlying tissues by a shear wave. The probe has a pulse-echo ultrasound to receive and measure the propagation of shear waves and their velocity which correspond to tissue stiffness [14]. In ARFI imaging, there are generated, localized, impulsive acoustic radiation forces conducting a dynamic tissue displacement and subsequently, tissue recovery to its original position. Inducted sheared waves in combination with ultrasound imaging ARFI facilitate the assessment of tissue stiffness in a selected tissue region of interest (ROI) [15]. An apparent limitation of the ARFI imaging is preset, constant size of ROI, and no information about standard deviation. SWE is a quantitative method based on an ultrasound probe generating radiation force and inducing simultaneously shear waves from different focal points. It influences the creation of the conical shear wave front. Progression of shear waves activates ultrasound images which are successively compared. As an outcome of induced tissue displacement, ultrasound imaging and its comparative peculiar image of tissue stiffness are being generated. The real-time image and capacity to measure tissue stiffness in a chosen direct area are the advantages of SWE [16].

Our goal was to provide an overview of ultrasound elastography as a potential diagnostic tool in inflammatory bowel disease to address the question whether it can support the stratification of IBD patients. Therefore, we conducted a systematic review of literature in order to investigate the utility of ultrasound elastography in assessment of intestinal changes in IBD.

\section{Materials and Methods}

To review the role of elastography in IBD patients, we have searched three publication databases: PubMed, World of Knowledge and Scopus. Combinations of the following keywords were used: ("elastography" or "ultrasound" or "SE" or "shear wave elastography" or "SWE" or "acoustic radiation force impulse" or "ARFI") AND ("Crohn's disease" or "ulcerative colitis" or "inflammatory bowel disease" or "IBD"). The search was limited to publications published between January 2015 and June 2021. Analysis of data was conducted according to PRISMA recommendations. Duplicate records from the databases were removed prior to the first eligibility screening. Exclusion criteria were as follows: experimental studies (including animal studies and in vitro research), non-IBD, non-original articles, on liver elastography in IBD and non-English language. Finally, we enrolled 12 publications to review. The search strategy has been summarized in Figure 1. 


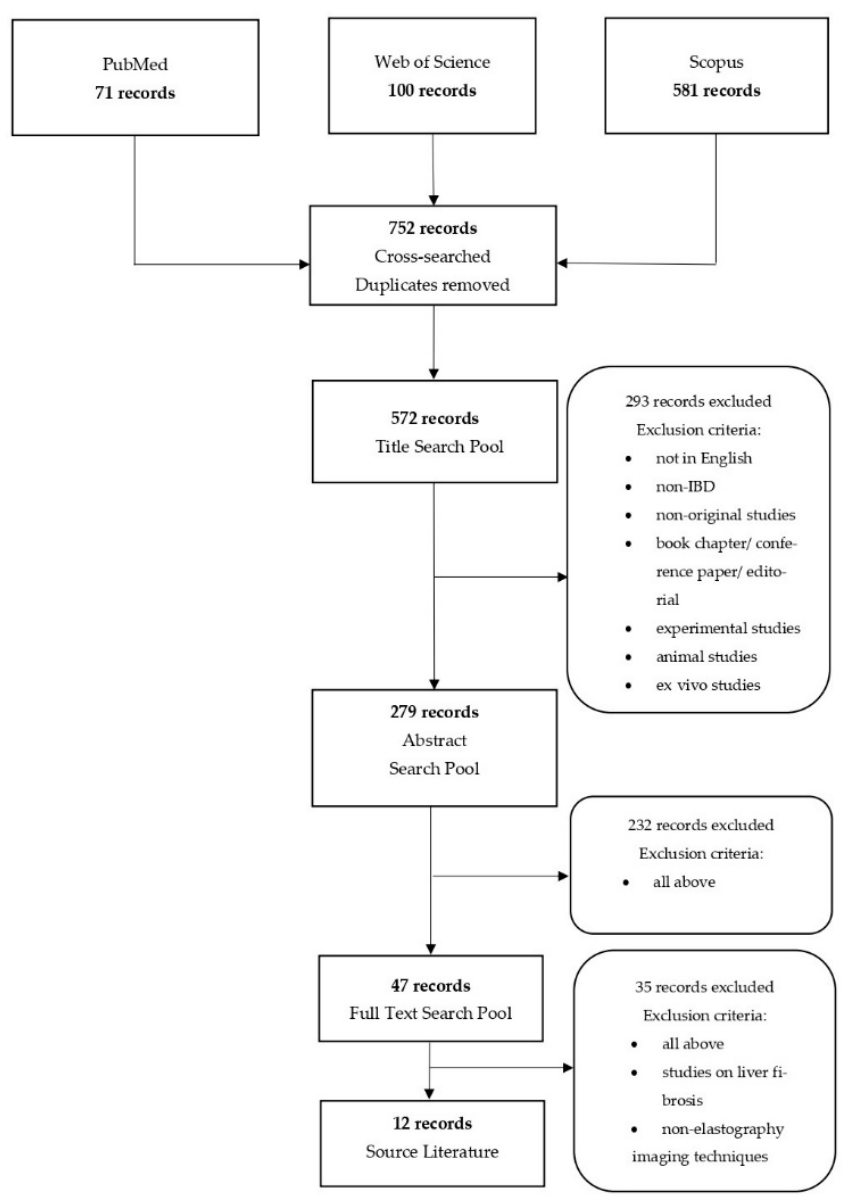

Figure 1. Flowchart presenting the selection process.

\section{Results}

\subsection{Interpretative Synthesis of Data: Elastography in CD}

A growing body of literature has investigated the applicability of ultrasound intestinal elastography in CD due to the whole wall inflammation and common fibrosis. The preliminary studies on this field were carried out with animal models and human subjects [17-19]. Since 2015, much more information on the usability of elastography in CD patients has become available [20-22]. Each of them used ultrasound elasticity imaging (UEI), although they implicated different reference methods. Nevertheless, studies suggested that ultrasound elastography may be a feasible technique for assessment of intestinal wall fibrosis in CD patients.

Baumgart et al. conducted research with 10 patients who had been elected for surgical intestinal resection due to the symptomatic stenosis. In order to perform an intestine evaluation, they examined bowel segments affected and unaffected by CD before, during and after surgery. Measurements of the intestinal wall had been performed via a built-in press guide function to generate repetitive compression and by direct tensiometry strain measurements intraoperatively. Tests revealed that the affected bowel segments had higher strain than unaffected. Furthermore, there was a significant correlation between histopathology findings, such as collagen content and elastography as well as tensiometry. The authors concluded that ultrasound-based real-time elastography can be used to reliably $(p<0.001)$ distinguish fibrotic from nonfibrotic tissue [20].

In turn, Fraquelli et al. assessed bowel strictures in 23 CD patients qualified for surgery and $20 \mathrm{CD}$ patients with active non-stricturing/non-penetrating disease. The evaluation was based on a comparative analysis between both the semi-quantitative visual color scale and ultrasound elastography imaging strain ratio measurements, and histopathological findings in respect to fibrosis and inflammation. The most remarkable result was the 
correlation of strain ratio and fibrosis severity. Study revealed that the UEI strain ratio had an excellent discriminatory ability for diagnosing severe bowel fibrosis, as assessed by AUROC (strain ratio: 0.917 ; 95\% CI, $0.788-1.000$; color scale: $0.680 ; 95 \%$ CI, $0.460-0.899$ ). From among standard US parameters, bowel wall thickness was significantly correlated with EI strain ratio. Moreover, patients with non-surgical, inflammatory $\mathrm{CD}$ had a lower strain ratio rather than surgical patients $(p=0.0005)$. No significant correlation was observed between color scale, stratification pattern and strain ratio [21].

Furthermore, Fufezan et al. introduced a novel method to evaluate the structure of the intestinal wall. They conducted strain elastography in 14 pediatric $C D$ patients in addition to hydrosonography (HS), clinical data and MRI (in 6 selected cases). They reported the correlation between HS findings, color doppler and SE pattern and strain ratio values $(p<0.005)$. Moreover, they showed correlation between disease activity markers and SE strain ratio value $(p<0.005)$ but not with fecal calprotectin level $(p=1065)$. Additionally, they put forward a color code to evaluate the inflammation and fibrosis of the intestinal wall. The main presumption was based on color code corresponding with tissue stiffness ("red-soft, green-intermediary stiffness, blue-hard") [22]. Due to elastography image, they distinguished three types of wall pattern: bowel in remission ("blue/green/blue"), inflammatory wall ("green/blue"), fibrotic wall ("blue"; no color stratification). The main weakness of the study is that authors did not correlate color stratification scale to histopathology evaluation.

Further research focused on proposing color patterns to assess intestinal fibrosis. Sconfienza et al. put forward an idea to divide SE axial image of the terminal ileum into eight equal parts. MRI was the reference technique in this experiment. Thereafter, each sector had to be estimated subsequently by a scale in which red $=1$ (minimal fibrosis), green $=2$ (intermediate fibrosis) and blue $=3$ (maximal fibrosis). Patients could receive from 8 to 24 points. A higher score was related to increased fibrotic tissue in the intestine. In the conclusion, the researchers reported that this method could possibly be a tool to estimate fibrosis in CD. However, using MRI as a referenced technique is a major flaw of their experiment [23]. Distinguishing fibrotic bowel segments from the inflamed ones by color pattern in compilation with MRI was also presented by Lo Re et al. [24].

A different outcome was presented by Serra et al. They enrolled $26 \mathrm{CD}$ patients with symptomatic stricturing disease. Seven days before surgery, each patient underwent ultrasonography with color-Doppler and strain elastography with strain ratio measurement. Results were correlated with a modified scoring system for inflammatory and fibrostenotic features of $C D$. In contrast with the previous research, Serra et al. reported that mean strain ratio measured during real-time strain elastography did not correlate with a histopathological score of inflammation $(p=0.531)$, fibrosis $(p=0.877)$ and clinical or biochemical markers: Harvey Bradshaw index (HBI) $(p=0.879)$, CRP $(p=0.485)$, previous ani-TNF therapy $(p=0.964)$. Moreover, the color-Doppler did not evaluate either gut inflammation $(p=0.764)$ or fibrosis $(p=0.288)[25]$.

A different point of view for ultrasound intestinal elastography was introduced by Quaia et al. The sensitivity and specificity of the conventional B-mode ultrasound, contrast-enhanced ultrasound (CEUS) and real-time strain elastography in combination were investigated. It was suggested that the correlation of these methods may be a visual, supportive tool in distinguishing fibrotic strictures. The research was limited by the application of mucosal deep biopsy as a referenced standard [26].

In line with the elastography technique enhancement, there has been a growing interest in ARFI and SWE imaging. In order to evaluate intestinal fibrosis and inflammation, Lu et al. conducted a study with the shear wave elastography using ARFI and contrastenhanced ultrasound. They enrolled in the study $95 \mathrm{CD}$ patients with stricturing disease. In 15 cases, surgery and histopathology assessment were performed. SWE mean value was significantly higher in a patient with surgery rather than without it $(p<0.01)$. They found out a moderate correlation between SWE and muscular hypertrophy which was 
more common in bowel strictures rather than fibrosis $(p=0.02)$. Furthermore, SWE did not correspond to fibrosis in histopathology samples [27].

Other researchers evaluated the utility of ARFI retrospectively (77 patients) and prospectively (21 patients). Stomach, (neo)terminal ileum and sigmoid were tested with ARFI. They reached the conclusion that, retrospectively, there is a correlation between ARFI and bowel wall thickness, Limberg score, CRP and HBI. Surprisingly, there was no dependence on elastography prospectively. The experiment was marred by using ultrasound parameters as a reference method and the different size of the analyzed group [28].

Further research was managed by Chen et al. [29]. They compared ultrasound image scored by Limberg classification, SWE and histology [30]. The study group consisted of $42 \mathrm{CD}$ patients ( 26 with strictures in terminal ileum, 9 in colon). They put forward a novel ultrasound classification method. At first, they estimated mild, moderate and severe fibrosis $(p=0.008)$ cut-off values $(14.4 \pm 2.1$ vs. $17.4 \pm 3.8$ vs. $23.0 \pm 6.3 \mathrm{Kpa})$ in SWE. The experiment was undermined by the lack of a control group to standardize new cut-off value. However, they pointed out that there was a significant correlation between the SWE mean value and intestinal fibrosis in spite of the inflammation [29]. In addition to SWE enhancements, Ding et al. conducted research to equate this method with TE. A comparative analysis of TE, ARFI and histopathology was performed on 25 patients. Both SE and ARFI imagine were divided into fibrosis stage by two visual color scales. They reported significant difference between mean shear wave velocity in inflammatory stenosis and fibrotic stenosis $(p<0.05)$. As a result, it was reported that only SWE achieved equitable sensitivity and specificity in detecting intestinal fibrosis [31]. It suggests that quantitative elastography methods are superior to qualitative (Table 1).

Table 1. Ultrasound elastography of intestines in Crohn's disease.

\begin{tabular}{|c|c|c|c|c|c|}
\hline Author & Year & $\begin{array}{l}\text { Total Subjects } \\
\text { Included }\end{array}$ & $\begin{array}{l}\text { Ultrasound } \\
\text { Elastography } \\
\text { Technique }\end{array}$ & Reference Standard & Main Findings \\
\hline Baumgart et al. [20] & 2015 & $\begin{array}{l}10 \text { CD patients with } \\
\text { ileocolonic CD and } \\
\text { symptomatic stenosis } \\
\text { that required surgery }\end{array}$ & $\begin{array}{c}\text { Pre-, intra- and } \\
\text { post-operative RTE }\end{array}$ & $\begin{array}{l}\text { Histologic evaluation } \\
\text { (morphometrics, } \\
\text { disease activity, } \\
\text { fibrosis); direct } \\
\text { tensiometry strain } \\
\text { measurement }\end{array}$ & $\begin{array}{l}\text { The aggregated RTE strain } \\
\text { mean values were } \\
\text { significantly higher in } \\
\text { unaffected than in affected } \\
\text { gut segments (mean, } \\
169.0 \pm 27.9 \text { vs. } 43.0 \pm 25.9 \\
p<0.001 \text { ). There was } \\
\text { significant association } \\
\text { between RTE and collagen } \\
\text { depositions. }\end{array}$ \\
\hline Fraquelli et al. [21] & 2015 & $\begin{array}{l}23 \mathrm{CD} \text { patients that } \\
\text { required surgery; } \\
20 \mathrm{CD} \text { patients with } \\
\text { active } \\
\text { non-structuring and } \\
\text { non-penetrating } \\
\text { disease }\end{array}$ & $\begin{array}{l}\text { UEI of terminal ileum } \\
\text { by means of color } \\
\text { scale and } \\
\text { quantitative strain } \\
\text { ratio measurement }\end{array}$ & $\begin{array}{l}\text { Semi-quantitative } \\
\text { and quantitative } \\
\text { histological image } \\
\text { analysis: scores for } \\
\text { fibrosis } \\
\text { (mild/moderate } \\
\text { versus severe) and } \\
\text { acute/chronic } \\
\text { inflammation (AIS, } \\
\text { CIS) }\end{array}$ & $\begin{array}{c}\text { The ileal strain ratio of } \\
\text { inflammatory CD patients } \\
\text { was significantly lower than } \\
\text { in operated CD patients with } \\
\text { severe fibrosis and was } \\
\text { significantly correlated with } \\
\text { the severity of bowel fibrosis } \\
\text { at histological analysis; it was } \\
\text { characterized by an excellent } \\
\text { discriminatory ability for } \\
\text { severe bowel fibrosis (AUC: } \\
\text { 0.917). }\end{array}$ \\
\hline Fufezan et al. [22] & 2015 & $\begin{array}{l}48 \text { bowel segments } \\
\text { (30 ileum and } \\
18 \text { colon) in } \\
14 \text { pediatric CD } \\
\text { patients }\end{array}$ & SE & $\begin{array}{l}\text { Hydrosonography, } \\
\text { clinical data, MRI } \\
\text { (6 patients) }\end{array}$ & $\begin{array}{c}\text { SE and SR correlated with } \\
\text { disease activity markers (ESR, } \\
\text { CRP) and hydrosonography } \\
\text { findings. }\end{array}$ \\
\hline
\end{tabular}


Table 1. Cont.

\begin{tabular}{|c|c|c|c|c|c|}
\hline Author & Year & $\begin{array}{l}\text { Total Subjects } \\
\text { Included }\end{array}$ & $\begin{array}{l}\text { Ultrasound } \\
\text { Elastography } \\
\text { Technique }\end{array}$ & Reference Standard & Main Findings \\
\hline Sconfienza et al. [23] & 2016 & 16 & $\begin{array}{l}\text { SE of terminal ileum } \\
\text { by means of color } \\
\text { map and } \\
\text { semi-quantitative } \\
\text { scale }\end{array}$ & MRI enterography & $\begin{array}{l}\text { RTS of the terminal ileum in } \\
\text { CD may differentiate between } \\
\text { fibrotic and inflammatory } \\
\text { strictures. }\end{array}$ \\
\hline Lu et al. [27] & 2017 & $\begin{array}{c}95 \text { patients; } \\
15 \text { patients had ileal } \\
\text { resection }\end{array}$ & SWE & $\begin{array}{l}\text { Histology (scores for } \\
\text { inflammation, } \\
\text { fibrosis, and } \\
\text { muscular } \\
\text { hypertrophy); CEUS }\end{array}$ & $\begin{array}{l}\text { SWE mean value was } \\
\text { significantly higher in a } \\
\text { patient with surgery rather } \\
\text { than without it }(p<0.01) \text {. } \\
\text { There was a moderate } \\
\text { correlation between SWE and } \\
\text { muscular hypertrophy and no } \\
\text { association between SWE and } \\
\text { fibrosis score. }\end{array}$ \\
\hline Serra et al. [25] & 2017 & $\begin{array}{l}26 \text { patients with } \\
\text { symptomatic } \\
\text { stricturing ileocolonic } \\
\text { CD that required } \\
\text { resection ( } 29 \text { bowel } \\
\text { segments) }\end{array}$ & SE & $\begin{array}{l}\text { Histopathology } \\
\text { evaluation of CD } \\
\text { (scoring system for } \\
\text { inflammatory and } \\
\text { fibrostenotic features) }\end{array}$ & $\begin{array}{c}\text { No significant correlation was } \\
\text { found between mean strain } \\
\text { ratio and fibrosis score ( } p= \\
0.877) .\end{array}$ \\
\hline Lo Re et al. [24] & 2017 & $\begin{array}{c}35 \\
\text { (41 affected bowel } \\
\text { segments and } \\
35 \text { unaffected) }\end{array}$ & SE & MRI & $\begin{array}{l}\text { There was a correlation } \\
\text { between US-SE color scale } \\
\text { and T2 signal intensity, and } \\
\text { between the US-SE color scale } \\
\text { and ADC maps. }\end{array}$ \\
\hline Quaia et al. [26] & 2018 & 20 & SE & Mucosal deep biopsy & $\begin{array}{l}\text { Combination of the } \\
\text { conventional B-mode } \\
\text { ultrasound, CEUS and RTSE } \\
\text { may support distinguishing } \\
\text { of fibrotic strictures. }\end{array}$ \\
\hline Goertz et al. [28] & 2018 & $\begin{array}{l}77 \text { retrospectively } \\
21 \text { prospectively }\end{array}$ & ARFI & $\begin{array}{c}\text { Ultrasound } \\
\text { parameters } \\
\text { (bowel wall thickness } \\
\text { and intramural } \\
\text { semi-quantitative } \\
\text { vascularization } \\
\text { grade) }\end{array}$ & $\begin{array}{l}\text { Retrospectively, the ARFI } \\
\text { values correlated with the } \\
\text { bowel wall thickness and } \\
\text { Limberg vascularization } \\
\text { score. Prospectively, there } \\
\text { was no correlation between } \\
\text { ARFI and bowel wall } \\
\text { thickness, Limberg score, } \\
\text { clinical activity, and CRP. A } \\
\text { cut-off analysis of } 105 \text { ileal } \\
\text { ARFI measurements showed } \\
\text { a cut-off value of } 1.92 \mathrm{~m} / \mathrm{s} \text { for } \\
\text { the diagnosis of ileal } \\
\text { inflammation with } 75.3 \% \\
\text { sensitivity and } 87.5 \% \\
\text { specificity. }\end{array}$ \\
\hline Chen et al. [29] & 2018 & $\begin{array}{l}35 \text { with } \\
\text { ileal/ileocolonic } \\
\text { symptomatic } \\
\text { strictures that } \\
\text { required surgical } \\
\text { resection }\end{array}$ & SWE & $\begin{array}{l}\text { Histology (score for } \\
\text { fibrotic and } \\
\text { inflammatory } \mathrm{CD} \text { ) }\end{array}$ & $\begin{array}{c}\text { The mean SWE value of } \\
\text { stenotic bowel wall was } \\
\text { significantly higher in severe } \\
\text { fibrosis ( } 23.0 \pm 6.3 \mathrm{Kpa} \text { ) than } \\
\text { that in moderate } \\
\text { (17.4 } \pm 3.8 \mathrm{Kpa} \text { ) and mild } \\
\text { fibrosis }(14.4 \pm 2.1 \mathrm{Kpa}) \\
\text { ( } p=0.008) \text {. Using } 22.55 \mathrm{KPa} \\
\text { as the cut-off value in } \\
\text { discriminating between } \\
\text { mild } / \text { moderate and severe } \\
\text { fibrosis, the sensitivity and } \\
\text { specificity was } 69.6 \% \text { and } \\
91.7 \% \text { (AUC } 0.822, p=0.002) \text {. }\end{array}$ \\
\hline
\end{tabular}


Table 1. Cont.

\begin{tabular}{|c|c|c|c|c|c|}
\hline Author & Year & $\begin{array}{l}\text { Total Subjects } \\
\text { Included }\end{array}$ & $\begin{array}{l}\text { Ultrasound } \\
\text { Elastography } \\
\text { Technique }\end{array}$ & Reference Standard & Main Findings \\
\hline Ding et al. [31] & 2019 & 25 & SE, ARFI, p-SWE & histology & $\begin{array}{c}\text { For SE, the optimal cut-off } \\
\text { value was a score of } 4 \text { or } \\
\text { greater (sensitivity, } 75 \% \text {; } \\
\text { specificity, } 66.7 \% \text {; accuracy, } \\
68 \% \text {; PPV, } 30 \% \text {; NPV, } 93.3 \% \text {; } \\
\text { AUROC, 0.708; however, } \\
\text { p > 0.05). For ARFI, the } \\
\text { optimal cut-off value was a } \\
\text { score of } 4 \text { or greater } \\
\text { (sensitivity, 50\%; specificity, } \\
81 \% \text {; accuracy, 76\%; PPV, } \\
33.3 \% \text {; NPV, } 89.4 \% \text {; AUROC, } \\
0.669 ; p<0.05 \text { ). For p-SWE, } \\
\text { the optimal cut-off value was } \\
\text { reached when the shear wave } \\
\text { velocity exceeded 2.73 m/s } \\
\text { (sensitivity, } 75 \% \text {; specificity, } \\
100 \% \text {; accuracy, 96\%; PPV, } \\
\text { 100\%; NPV, } 95.5 \% \text {; AUROC, } \\
0.833 ; p<0.05 \text { ). }\end{array}$ \\
\hline
\end{tabular}

ARFI, acoustic radiation force impulse; MRI, magnetic resonance imaging; SE, strain elastography; SWE, shear wave elastography; MR, magnetic resonance; US, ultrasonography; RTE, real-time elastography; AUROC, area under the receiver operating characteristic curve; AIS, acute inflammatory score; CIS, chronic inflammatory score; ADC, apparent diffusion coefficient; CEUS, contrast enhanced ultrasound; CRP, C-reactive protein, p-SWE; point shear wave elastography.

\subsection{Interpretative Synthesis of Data: Elastography in UC}

We were able to find one study on ultrasound elastography in ulcerative colitis [32]. Goertz et al. performed ARFI shear wave elastography in 20 UC patients. The authors evaluated ascending, transverse, descending and sigmoid colon in UC patients and healthy volunteers in compilation with ultrasound wall thickness assessment and vascularization scale. The ROI region was targeted into the whole wall (collapsed partially in healthy volunteers and diseased in UC patients). The study has shown that ARFI values were higher in UC patients than in controls $(p=0.021)$, especially in transverse $(p=0.045)$ and sigmoid colon $(p=0.032)$. No correlation between ARFI values and wall thickness, Limberg score or clinical Mayo-Subscore raised a concern that the data was not compared to a more validated method, such as MRI or colonoscopy (Table 2).

Table 2. Ultrasound elastography of intestines in ulcerative colitis.

\begin{tabular}{ccccc}
\hline Author & Year & $\begin{array}{c}\text { Total Subjects } \\
\text { Included }\end{array}$ & $\begin{array}{c}\text { Ultrasound } \\
\text { Elastography } \\
\text { Technique }\end{array}$ & $\begin{array}{c}\text { Reference } \\
\text { Standard }\end{array}$ \\
\hline Goertz et al. [32] & 2019 & $\begin{array}{c}\text { M UC } \\
13 \text { non-IBD }\end{array}$ & ARFI & $\begin{array}{c}\text { ARFI values were } \\
\text { higher in UC than } \\
\text { in control group }\end{array}$ \\
\hline
\end{tabular}

ARFI, acoustic radiation force impulse; non-IBD, non- inflammatory bowel disease; UC, ulcerative colitis.

\section{Discussion}

Inflammatory bowel disease, due to the increasing incidence worldwide, changing age profile of patients, unclear pathogenesis, unavailable simple diagnostic algorithm and missing effective therapy, comprises a currently significant health burden. IBD management is inseparably connected with several imaging modalities which support the diagnosis establishment, stratification of patients and therapeutic decisions. Ultrasound elastography is a novel radiation- and contrast-free option which is assessed in IBD. 
As expected, the majority of the studies on UE in IBD were focused on Crohn's disease patients. From among 11 studies, 5 included patients with symptomatic strictures in ileocolonic region. The authors were able to demonstrate the effectiveness of UE in recognizing fibrotic type of strictures.

Occurrence of strictures in Crohn's disease may be associated with inflammation, fibrosis or malignancy. Fibrosis in $\mathrm{CD}$ refers to accumulation of collagen and fibronectin extracellular matrix (ECM) produced by mesenchymal cells, such as fibroblasts, myofibroblasts and smooth muscle cells as an effect of chronic inflammation and increased levels of cytokines, chemokines and growth factors [33,34]. Previous research has shown that $4.6 \%$ of the patients had stricturing disease and the cumulative risk of developing com-plication increases to $50.8 \%$ after 20 years of the disease duration [35]. As recently reviewed by Mak and $\mathrm{Ng}$, up to $20 \%$ of $\mathrm{CD}$ patients present with strictures at diagnosis that may arise, similarly to the inflammatory changes in every segment of the gastrointestinal tract affecting, the most frequently, ileum alone (30-45\%) and ileocolonic region (40-60\%). Moreover, despite being found less often than in CD patients, strictures are also found in $1-11 \%$ of UC patients [36]. Despite the huge progress in the implementation of novel therapeutic agents into clinical practice, it was demonstrated that they do not influence the occurrence of fibrosis. In a recently published systematic review on nonsurgical therapy of CD-related strictures from among drug therapy only, anti-TNF $\alpha$ agents appeared to be effective in preventing surgery as during 4 years of follow-up, 50\% of patients could escape operation [37]. Unfortunately, antifibrotic therapy is not available. Several options of endoscopic and surgical interventions for strictures related with $C D$ have been developed in order to resolve clinical symptoms and improve a patient's quality of life. Therapeutic approach varies up from stricture pathology, which may be fibrotic, inflammatory, mixed or, the most importantly, malignant. Therefore, precise preoperative evaluation of the stenosis character has a crucial role for the therapeutic strategy [38].

Recognizing the intestinal complications of IBD involves endoscopy as well as CT or MR imaging. MRI or/and intestinal ultrasound are recommended in the detection of strictures in CD. There is no imaging technique to evaluate the degree of fibrosis [39]. Further, biomarkers of fibrostenosing Crohn's disease are unavailable, despite some such as cartilage oligomeric matrix protein, hepatocyte growth factor activator, and lower levels of microRNA-19-3p which are promising [40]. Several options have been proposed to assess fibrosis in CD with some focusing on MRI, others on ultrasound elastography [41,42].

Yet, due to the heterogenicity of the studies included in our analysis, drawing out the final conclusions has to be done carefully. First of all, the authors applied various ultrasound elastography techniques which results from the constant development of this diagnostic modality. For instance, as described above, every UE option has a distinct way to provide findings, from semi-quantitative color maps to quantitative results. Yet, there are different cut-off values proposed for diagnosing fibrosis. Secondly, the authors employed various reference standards: histology, MRI, hydrosonography and ultrasonography. Moreover, among the studies with histological reference, there were different histological scores utilized. In line with development of research on ultrasound elastography, the reference techniques to distinguish intestinal inflammation and fibrosis are needed. Currently, there is no gold standard in intestinal fibrosis assessment, however, histological evaluation is claimed to be the most aware. Still, there is no general agreement on histology scoring of fibromuscular stenosis [30]. Second, the most frequently applied method after histology was MRI. In recent years, there has been a growing interest in MRI feasibility in detecting and evaluating intestinal fibrosis. Various approaches have been proposed to solve the issue. Diffusion-weighted MRI (DW-MRI), contrast-enhanced MRI (CE-MRI) and magnetization transfer MRI (MT-MRI) are suggested to distinguish fibrosis and inflammation. However, there is no validated imaging technique to assess the degree of fibrosis [41].

Prior types of research were focused on SE. However, there is an increasing number of studies on ARFI and SWE imaging. Early studies tended to be focused on color fibrosis mapping and later, on strain measurement. Previously published articles have a few major 
flaws. Firstly, all of them were conducted in small groups. Secondly, approximately only half of the introduced studies used histology as a reference method. Histology claims to be the most relative technique to estimate intestinal fibrosis, in spite of the fact that there is still no general agreement on the histological scoring system of stenosis in CD [30]. In other types of research, elastography was compared to the less validated methods, such as MRI, hydrosonography, mucosal deep biopsy, ultrasound parameters (bowel wall thickness and intramural semi-quantitative vascularization grade) and/or clinical data.

In spite of the fact that UC affects rectal or/and colonic mucosa, so the elastography may not be as effective as in $\mathrm{CD}$, several studies were conducted to assess elastography implication in UC. One of the first researches on elastography in ulcerative colitis was conducted by Ishikawa et al. in a group of 37 patients with left-sided colitis or pancolitis [43]. Authors applied real-time tissue sonoelastography (EG), a method which assesses tissue stiffness during ultrasound by freehand compression. In turn, Rustemovic et al. investigated the applicability of transrectal ultrasound (TRUS) elastography in IBD patients. The authors concluded that transrectal ultrasound elastography is a promising diagnostic tool in distinguishing CD and UC [44]. After January 2015, we were able to find only one study which was focused on elastography in UC. The authors demonstrated that ARFI values in UC patients were higher than in controls. However, the study was conducted on a small group of patients and the reference method was also debatable.

Limitations of our research result from the heterogenous character of available studies on ultrasound elastography of intestines in IBD. First of all, included studies applied different techniques of ultrasound elastography and various reference standards. Furthermore, this novel imaging method is continuously developing.

\section{Conclusions}

In conclusion, elastography is a promising novel imaging technique to evaluate intestinal strictures in Crohn's patients. Further research on larger groups of patients with both CD and UC are needed in order to establish the ultrasound elastography protocol and to validate cut-off values of intestinal wall fibrosis.

Author Contributions: Conceptualization, D.Ś., K.N., E.P. and R.K.; methodology, D.Ś., R.K. and K.N.; formal analysis, D.Ś., K.N. and R.K.; investigation, D.Ś., K.N. and R.K.; writing-original draft preparation, D.Ś., K.N. and R.K.; writing-review and editing, D.Ś., K.N. and R.K.; visualization, K.N. and R.K.; supervision, K.N. and R.K.; funding acquisition, E.P. All authors have read and agreed to the published version of the manuscript.

Funding: The APC was funded by Wroclaw Medical University SUB.C131.21.043.

Conflicts of Interest: The authors declare no conflict of interest.

\section{References}

1. Ng, S.C.; Shi, H.Y.; Hamidi, N.; Underwood, F.E.; Tang, W.; Benchimol, E.I.; Panaccione, R.; Ghosh, S.; Wu, J.C.Y.; Chan, F.K.L.; et al. Worldwide incidence and prevalence of inflammatory bowel disease in the 21st century: A systematic review of population-based studies. Lancet 2018, 390, 2769-2778. [CrossRef]

2. Torres, J.; Mehandru, S.; Colombel, J.F.; Peyrin-Biroulet, L. Crohn's disease. Lancet 2017, 389, 1741-1755. [CrossRef]

3. Graham, D.B.; Xavier, R.J. Pathway paradigms revealed from the genetics of inflammatory bowel disease. Nature 2020, 578, 527-539. [CrossRef] [PubMed]

4. Magro, F.; Langner, C.; Driessen, A.; Ensari, A.; Geboes, K.; Mantzaris, G.J.; Villanacci, V.; Becheanu, G.; Borralho Nunes, P.; Cathomas, G.; et al. European consensus on the histopathology of inflammatory bowel disease. J. Crohn's Colitis 2013, 7, 827-851. [CrossRef] [PubMed]

5. Zakeri, N.; Pollok, R.C. Diagnostic imaging and radiation exposure in inflammatory bowel disease. World J. Gastroenterol. 2016, 22, 2165-2178. [CrossRef]

6. Bromke, M.A.; Neubauer, K.; Kempiński, R.; Krzystek-Korpacka, M. Faecal calprotectin in assessment of mucosal healing in adults with inflammatory bowel disease: A meta-analysis. J. Clin. Med. 2021, 10, 2203. [CrossRef]

7. Garra, B.S. Elastography: History, principles, and technique comparison. Abdom. Imaging 2015, 40, 680-697. [CrossRef]

8. Friedrich-Rust, M.; Poynard, T.; Castera, L. Critical comparison of elastography methods to assess chronic liver disease. Nat. Rev. Gastroenterol. Hepatol. 2016, 13, 402-411. [CrossRef] 
9. Kim, J.R.; Suh, C.H.; Yoon, H.M.; Lee, J.S.; Cho, Y.A.; Jung, A.Y. The diagnostic performance of shear-wave elastography for liver fibrosis in children and adolescents: A systematic review and diagnostic meta-analysis. Eur. Radiol. 2018, 28, 1175-1186. [CrossRef]

10. Sigrist, R.M.; Liau, J.; Kaffas, A.E.; Chammas, M.C.; Willmann, J.K. Ultrasound elastography: Review of techniques and clinical applications. Theranostics 2017, 7, 1303-1329. [CrossRef]

11. Kawada, N.; Tanaka, S. Elastography for the pancreas: Current status and future perspective. World J. Gastroenterol. 2016, 22, 3712-3724. [CrossRef]

12. Dietrich, C.F.; Barr, R.G.; Farrokh, A.; Dighe, M.; Hocke, M.; Jenssen, C.; Dong, Y.; Saftoiu, A.; Havre, R.F. Strain elastographyHow to do it? Ultrasound Int. Open 2017, 3, E137-E149. [CrossRef] [PubMed]

13. Cosgrove, D.; Piscaglia, F.; Bamber, J.; Bojunga, J.; Correas, J.M.; Gilja, O.H.; Klauser, A.S.; Sporea, I.; Calliada, F.; Cantisani, V.; et al. EFSUMB Guidelines and recommendations on the clinical use of ultrasound elastography part 2: Clinical applications. Ultraschall Med. 2013, 34, 238-253. [CrossRef] [PubMed]

14. Afdhal, N.H. Fibroscan (transient elastography) for the measurement of liver fibrosis. Gastroenterol. Hepatol. $2012,8,605-607$.

15. Nightingale, K. Acoustic radiation force impulse (ARFI) imaging: A review. Curr. Med. Imaging Rev. 2011, 7, 328-339. [CrossRef]

16. Sarvazyan, A.; Hall, T.J.; Urban, M.W.; Fatemi, M.; Aglyamov, S.R.; Garra, B.S. An overview of elastography-An emerging branch of medical imaging. Curr. Med. Imaging Rev. 2011, 7, 255-282. [CrossRef]

17. Kim, K.; Johnson, L.A.; Jia, C.; Joyce, J.C.; Rangwalla, S.; Higgins, P.D.; Rubin, J.M. Noninvasive ultrasound elasticity imaging (UEI) of Crohn's disease: Animal model. Ultrasound Med. Biol. 2008, 34, 902-912. [CrossRef]

18. Stidham, R.W.; Xu, J.; Johnson, L.A.; Kim, K.; Moons, D.S.; McKenna, B.J.; Rubin, J.M.; Higgins, P.D. Ultrasound elasticity imaging for detecting intestinal fibrosis and inflammation in rats and humans with Crohn's disease. Gastroenterology 2011, 141, 819-826. [CrossRef]

19. Dillman, J.R.; Stidham, R.W.; Higgins, P.D.; Moons, D.S.; Johnson, L.A.; Rubin, J.M. US elastography-derived shear wave velocity helps distinguish acutely inflamed from fibrotic bowel in a Crohn's disease animal model. Radiology 2013, 267, 757-766. [CrossRef]

20. Baumgart, D.C.; Müller, H.P.; Grittner, U.; Metzke, D.; Fischer, A.; Guckelberger, O.; Pascher, A.; Sack, I.; Vieth, M.; Rudolph, B. US-based real-time elastography for the detection of fibrotic gut tissue in patients with stricturing Crohn disease. Radiology 2015, 275, 889-899. [CrossRef]

21. Fraquelli, M.; Branchi, F.; Cribiù, F.M.; Orlando, S.; Casazza, G.; Magarotto, A.; Massironi, S.; Botti, F.; Contessini-Avesani, E.; Conte, D.; et al. The role of ultrasound elasticity imaging in predicting ileal fibrosis in Crohn's disease patients. Inflamm. Bowel Dis. 2015, 21, 2605-2612. [CrossRef]

22. Fufezan, O.; Asavoaie, C.; Tamas, A.; Farcau, D.; Serban, D. Bowel elastography-a pilot study for developing an elastographic scoring system to evaluate disease activity in pediatric Crohn's disease. Med. Ultrason. 2015, 17, 422-430. [CrossRef]

23. Sconfienza, L.M.; Cavallaro, F.; Colombi, V.; Pastorelli, L.; Tontini, G.; Pescatori, L.; Esseridou, A.; Savarino, E.; Messina, C.; Casale, R.; et al. In-vivo axial-strain sonoelastography helps distinguish acutely-inflamed from fibrotic terminal ileum strictures in patients with Crohn's disease: Preliminary results. Ultrasound Med. Biol. 2016, 42, 855-863. [CrossRef]

24. Lo Re, G.; Picone, D.; Vernuccio, F.; Scopelliti, L.; Di Piazza, A.; Tudisca, C.; Serraino, S.; Privitera, G.; Midiri, F.; Salerno, S.; et al. Comparison of US strain elastography and entero-MRI to typify the mesenteric and bowel wall changes during Crohn's disease: A pilot study. BioMed Res. Int. 2017, 2017, 4257987. [CrossRef]

25. Serra, C.; Rizzello, F.; Pratico', C.; Felicani, C.; Fiorini, E.; Brugnera, R.; Mazzotta, E.; Giunchi, F.; Fiorentino, M.; D’Errico, A.; et al. Real-time elastography for the detection of fibrotic and inflammatory tissue in patients with stricturing Crohn's disease. J. Ultrasound 2017, 20, 273-284. [CrossRef]

26. Quaia, E.; Gennari, A.G.; Cova, M.A.; van Beek, E.J. Differentiation of inflammatory from fibrotic ileal strictures among patients with Crohn's disease based on visual analysis: Feasibility study combining conventional B-mode ultrasound, contrast-enhanced ultrasound and strain elastography. Ultrasound Med. Biol. 2018, 44, 762-770. [CrossRef] [PubMed]

27. Lu, C.; Gui, X.; Chen, W.; Fung, T.; Novak, K.; Wilson, S.R. Ultrasound shear wave elastography and contrast enhancement: Effective biomarkers in Crohn's disease strictures. Inflamm. Bowel Dis. 2017, 23, 421-430. [CrossRef]

28. Goertz, R.S.; Lueke, C.; Wildner, D.; Vitali, F.; Neurath, M.F.; Strobel, D. Acoustic radiation force impulse (ARFI) elastography of the bowel wall as a possible marker of inflammatory activity in patients with Crohn's disease. Clin. Radiol. 2018, 73. [CrossRef] [PubMed]

29. Chen, Y.J.; Mao, R.; Li, X.H.; Cao, Q.H.; Chen, Z.H.; Liu, B.X.; Chen, S.L.; Chen, B.L.; He, Y.; Zeng, Z.R.; et al. Real-time shear wave ultrasound elastography differentiates fibrotic from inflammatory strictures in patients with Crohn's disease. Inflamm. Bowel Dis. 2018, 24, 2183-2190. [CrossRef] [PubMed]

30. Sasaki, T.; Kunisaki, R.; Kinoshita, H.; Kimura, H.; Kodera, T.; Nozawa, A.; Hanzawa, A.; Shibata, N.; Yonezawa, H.; Miyajima, E.; et al. Doppler ultrasound findings correlate with tissue vascularity and inflammation in surgical pathology specimens from patients with small intestinal Crohn's disease. BMC Res. Notes 2014, 7, 363. [CrossRef] [PubMed]

31. Ding, S.S.; Fang, Y.; Wan, J.; Zhao, C.K.; Xiang, L.H.; Liu, H.; Pu, H.; Xu, G.; Zhang, K.; Xu, X.R.; et al. Usefulness of strain elastography, ARFI imaging, and point shear wave elastography for the assessment of Crohn disease strictures. J. Ultrasound Med. 2019, 38, 2861-2870. [CrossRef] [PubMed]

32. Goertz, R.S.; Lueke, C.; Schellhaas, B.; Pfeifer, L.; Wildner, D.; Neurath, M.F.; Strobel, D. Acoustic radiation force impulse (ARFI) shear wave elastography of the bowel wall in healthy volunteers and in ulcerative colitis. Acta Radiol. Open 2019, 8. [CrossRef] 
33. De Bruyn, J.R.; van den Brink, G.R.; Steenkamer, J.; Buskens, C.J.; Bemelman, W.A.; Meisner, S.; Muncan, V.; te Velde, A.A.; D'Haens, G.R.; Wildenberg, M.E. Fibrostenotic phenotype of myofibroblasts in Crohn's disease is dependent on tissue stiffness and reversed by LOX inhibition. J. Crohn's Colitis 2018, 12, 849-859. [CrossRef] [PubMed]

34. Rieder, F.; Fiocchi, C.; Rogler, G. Mechanisms, management, and treatment of fibrosis in patients with inflammatory bowel diseases. Gastroenterology 2017, 152, 340-350. [CrossRef] [PubMed]

35. Thia, K.T.; Sandborn, W.J.; Harmsen, W.S.; Zinsmeister, A.R.; Loftus, E.V. Risk factors associated with progression to intestinal complications of Crohn's disease in a population-based cohort. Gastroenterology 2010, 139, 1147-1155. [CrossRef]

36. Mak, J.W.Y.; Ng, S.C. Epidemiology of fibrostenosing inflammatory bowel disease. J. Dig. Dis. 2020, 21, 332-335. [CrossRef] [PubMed]

37. Schulberg, J.D.; Wright, E.K.; Holt, B.A.; Wilding, H.E.; Hamilton, A.L.; Ross, A.L.; Kamm, M.A. Efficacy of drug and endoscopic treatment of Crohn's disease strictures: A systematic review. J. Gastroenterol. Hepatol. 2020, 36, 344-361. [CrossRef] [PubMed]

38. Mohan, H.M.; Coffey, J.C. Surgical treatment of intestinal stricture in inflammatory bowel disease. J. Dig. Dis. 2020, 21, 355-359. [CrossRef] [PubMed]

39. Maaser, C.; Sturm, A.; Vavricka, S.R.; Kucharzik, T.; Fiorino, G.; Annese, V.; Calabrese, E.; Baumgart, D.C.; Bettenworth, D.; Nunes, P.B.; et al. ECCO-ESGAR Guideline for diagnostic assessment in IBD Part 1: Initial diagnosis, monitoring of known IBD, detection of complications. J. Crohn's Colitis 2019, 13, 144-164. [CrossRef]

40. Steiner, C.A.; Berinstein, J.A.; Louissaint, J.; Higgins, P.D.R.; Spence, J.R.; Shannon, C.; Lu, C.; Stidham, R.W.; Fletcher, J.G.; Bruining, D.H.; et al. Biomarkers for the Prediction and Diagnosis of Fibrostenosing Crohn's Disease: A Systematic Review. Clin. Gastroenterol. Hepatol. 2021. [CrossRef] [PubMed]

41. Bettenworth, D.; Bokemeyer, A.; Baker, M.; Mao, R.; Parker, C.E.; Nguyen, T.; Ma, C.; Panés, J.; Rimola, J.; Fletcher, J.G.; et al. Assessment of Crohn's disease-associated small bowel strictures and fibrosis on cross-sectional imaging: A systematic review. Gut 2019, 68, 1115-1126. [CrossRef] [PubMed]

42. El Ouali, S.; Click, B.; Holubar, S.D.; Rieder, F. Natural history, diagnosis and treatment approach to fibrostenosing Crohn's disease. United Eur. Gastroenterol. J. 2020, 8, 263-270. [CrossRef]

43. Ishikawa, D.; Ando, T.; Watanabe, O.; Ishiguro, K.; Maeda, O.; Miyake, N.; Nakamura, M.; Miyahara, R.; Ohmiya, N.; Hirooka, Y.; et al. Images of colonic real-time tissue sonoelastography correlate with those of colonoscopy and may predict response to therapy in patients with ulcerative colitis. BMC Gastroenterol. 2011, 11, 29. [CrossRef] [PubMed]

44. Rustemovic, N.; Cukovic-Cavka, S.; Brinar, M.; Radić, D.; Opacic, M.; Ostojić, R.; Vucelic, B. A pilot study of transrectal endoscopic ultrasound elastography in inflammatory bowel disease. BMC Gastroenterol. 2011, 11, 113. [CrossRef] 